\title{
Degradation of tribromophenol by wood-rot fungi and hamilton system
}

\author{
Mariel Monrroy \\ Centro de Biotecnología \\ Laboratorio de Recursos Renovables \\ Facultad de Ciencias Forestales \\ Universidad de Concepción \\ Casilla 160-C \\ Concepción, Chile \\ Tel: 5641204601 \\ Fax: 5641247517 \\ E-mail: mmonrroy@udec.cl \\ Juanita Freer \\ Centro de Biotecnología \\ Laboratorio de Recursos Renovables \\ Facultad de Ciencias Químicas \\ Universidad de Concepción \\ Casilla 160-C \\ Concepción, Chile \\ Tel: 5641204601 \\ Fax: 5641247517 \\ E-mail: jfreer@udec.cl
}

\section{Jaime Baeza}

Centro de Biotecnología

Laboratorio de Recursos Renovables

Facultad de Ciencias Químicas

Universidad de Concepción

Casilla 160-C

Concepción, Chile

Tel: 5641204601

Fax: 5641247517

E-mail: jbaeza@udec.cl

\section{Jaime Rodríguez*}

Centro de Biotecnología

Laboratorio de Recursos Renovables

Facultad de Ciencias Forestales

Universidad de Concepción

Casilla 160-C

Concepción, Chile

Tel: 5641204601

Fax: 5641247517

E-mail: jrodrig@udec.cl

Financial support: ALFA-European Union Program, the FONDECYT-Chile Program (grant No 1040619).

Keywords: biological treatment, combined treatment, mineralization, toxicity, tribromophenol.

Abbreviations: DHB: dihidroxybencenes

EPA: Environmental Protection Agency

PCPNa: sodium pentachlorophenate

TBP: 2,4,6-tribromophenol

TBPNa: sodium tribromophenate

Biological, chemical and combined treatments were used to degrade TBP. The biological treatment consisted in the use of Laetiporus sulphureus, Gloeophyllum trabeum and Ganoderma australe, which respectively achieved $48 \%, 74 \%$ and $80 \%$ degradation, and $40 \%$, $70 \%$ and $77 \%$ of organic bromine removal (AOX) on TBP water solutions $\left(60 \mathrm{mg} \mathrm{L}^{-1}\right)$ after 15 days of bio treatment. The biological treatment with $\mathrm{G}$. australe on

* Corresponding author 
TBP-contaminated sawdust $\left(10 \mathrm{mg} \mathrm{kg}^{-1}\right)$ led to $23 \%$ degradation. The chemical treatment consisted in the Hamilton system (Fenton reaction assisted by 1,2dihydroxybenzene); observing with this treatment, $95 \%$ degradation, $50 \%$ mineralization (TOC), and $48 \%$ reduction of chemical oxygen demand (COD). The combined treatment of both (chemical-biological) treatments produced degradations of $100 \%$, and reduction of toxicity of $34 \%$ and $30 \%$, with $L$. sulphureus and G. australe, respectively.

In 1998, TBP, a compound of acute toxicity, was incorporated by the Environmental Protection Agency (EPA, USA) to the list of hazardous wastes (EPA, 1998).This compound is used as a large-scale biocide, and especially as a wood preservative. In Chile, TBPNa has been used in recent years, as substitute to PCPNa to prevent the wood stained chromogenous fungi (CONAMA, 2000). One result of its application is that TBP is frequently found in soils, sawdust and waters, where it is toxic and dangerous for human health and the environment. One technology that has been successfully used in the decontamination of soils and waters containing recalcitrant compounds is the application of wood-degrading fungi (Yadav and Reddy, 1993; Eggen, 1999; Schützendübel et al. 1999; Sholosser et al. 2000; Newcombe et al. 2002). In degradation processes, in addition to enzymatic systems, these fungi have advanced oxidation systems, such as the Fenton reaction (Sholosser et al. 2000; Jensen et al. 2001), which are assisted by low molecular mass compounds, such as DHB, that have the capacity to reduce and link metals (Shimada et al. 1997; Paszczynski et al. 1999; Qian et al. 2002; Wang and Gao, 2003).

This study evaluated the TBP degradation by a biological treatment (using Ganoderma australe, Gloeophyllum trabeum y Laetiporus sulphureus) and a chemical treatment with $1,2-\mathrm{DHB} / \mathrm{Fe}^{3+} / \mathrm{H}_{2} \mathrm{O}_{2}$ simulating the advanced oxidation system of fungi. The combined chemical-biological treatment was also tested.

\section{MATERIALS AND METHODS}

\section{Biological treatment}

Fungal strains G. trabeum ATCC 11539, L. sulphureus ATCC 52600 and G. australe IJFM, CIB-CSIC (Madrid, Spain) were pre-grown in Petri dishes with dextrose potato agar medium (3.9\%) at $25^{\circ} \mathrm{C}$ for 10 days. Subsequently, 3 discs (10 mm of diameter) of mycelia were removed and added to a 125-mL Erlenmeyer flask containing $25 \mathrm{~mL}$ liquid culture (buffered with $20 \mathrm{mM}$ 2,2- dimethylsuccinic acid sodium salt at $\mathrm{pH} 4.5$ and incubated at $25 \mathrm{rpm}$ at $25^{\circ} \mathrm{C}$ for 3 days. Then, TBP solutions ( $5 \%$ ethanol) were added to liquid culture to produce a final concentration of $60 \mathrm{mg} \mathrm{L}^{-1}$. Flasks were incubated at $25 \mathrm{rpm}$ for 20 days, quantifying every 4 days. The liquid culture was filtered with glass wool and $0.22 \mu \mathrm{m}$ nitrocellulose filter. The filtered was analyzed by high-performance liquid chromatographic (HPLC) and adsorbable organic halides (AOX).

For TBP degradation in sawdust, $8 \mathrm{~g}$ sawdust of Eucalyptus globulus, previously hydrated were mixed with $1 \mathrm{~mL}$ TBP solution for $10 \mu \mathrm{g}$ TBP/sawdust g (dry weight) concentration, $\mathrm{pH}$ was adjusted to 5 , incubated for 1 day and then inoculated with $18 \mathrm{mg}$ of G. australe (dry weight) and incubated to $25^{\circ} \mathrm{C}$ for 20 days. TBP concentration was determined every 5 days by gas chromatography with electron detector (GC-ECD).
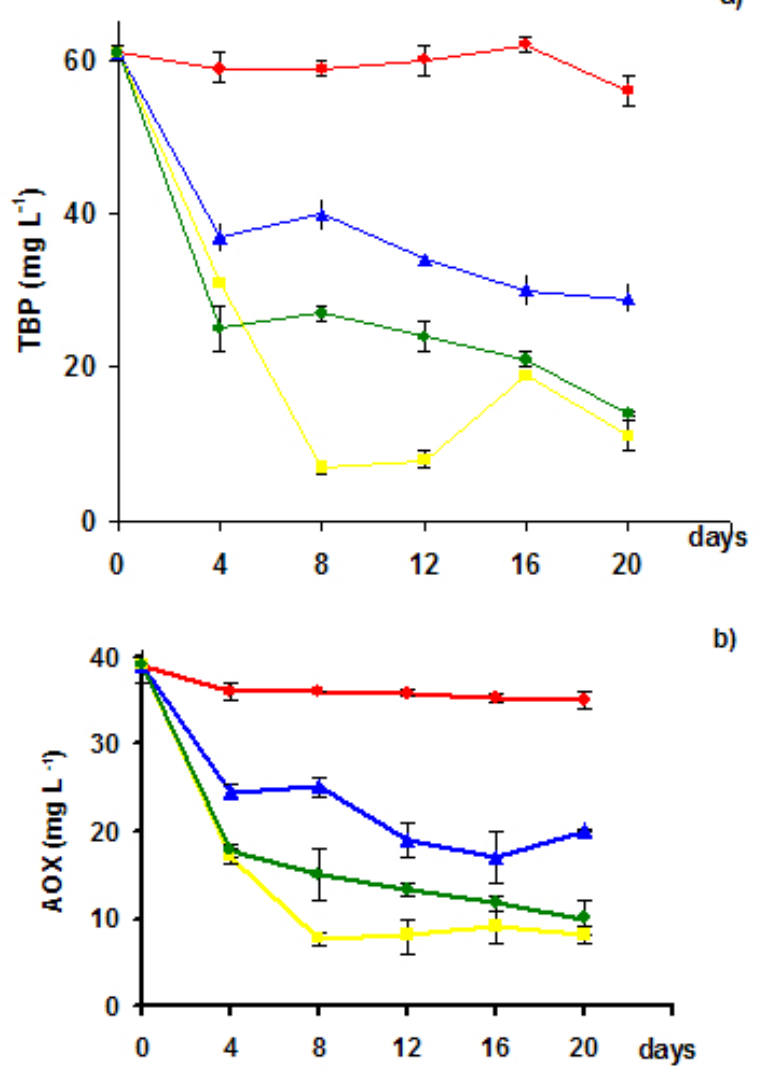

Figure 1. Concentration $\left(\mathrm{mg} \mathrm{L}^{-1}\right)$ in liquid culture for $G$. trabeum $(\bullet)$, L. sulphureus $(\boldsymbol{\Delta})$ and G. australe $(\square)$. Control $(\bullet)$ : (a) TBP and (b) AOX. (Value represents means \pm S.D. for triplicate cultures).

\section{Chemical treatment}

To $10 \mathrm{ml}$ TBP $\left(60 \mathrm{mg} \mathrm{L}^{-1}\right)$, the following were added in the order indicated $25 \mu \mathrm{M} 1.2 \mathrm{DHB}, 38 \mu \mathrm{M} \mathrm{FeCl} 3 . \mathrm{H}_{2} \mathrm{O}, 980$ $\mu \mathrm{M} \mathrm{H}_{2} \mathrm{O}_{2}$ (Hamilton system), $\mathrm{pH}$ adjusted to 3 , and kept at $25^{\circ} \mathrm{C}$ in the dark. TBP degradation was evaluated every $1 \mathrm{hr}$ for 10 hrs by HPLC and total organic carbon (TOC). Toxicity (MICROTOX ${ }^{\circledR}$ ) and chemical oxygen demand (COD) were measured at the end of the reaction. Treatment optimal conditions for Hamilton system were previously determined by multivariate analysis in other study in our laboratory (Rojo et al. 2004). 


\section{Chemical-biological treatment}

Mycelium of fungi previously grown in a liquid medium for three days, as described earlier, was washed with abundant sterilized water, and then added to chemically treated samples (during 10 days). Later, inoculated samples were incubated at $25 \mathrm{rpm}, 30^{\circ} \mathrm{C}$ for 5 days. The samples were analyzed by HPLC and MICROTOX ${ }^{\circledR}$.

\section{Analytical procedures}

TBF degradation was monitored by HPLC and GC-ECD. AOX was determined in Euroglas ESC 1000. Mineralization was monitored using a Shimadzu TOC-5050 system and COD by spectrophotometric UV-VIS. For acute toxicity determination luminescent bacteria were used, specifically the strain Vibrio fischeri and MICROTOX ${ }^{\circledR}$ system.

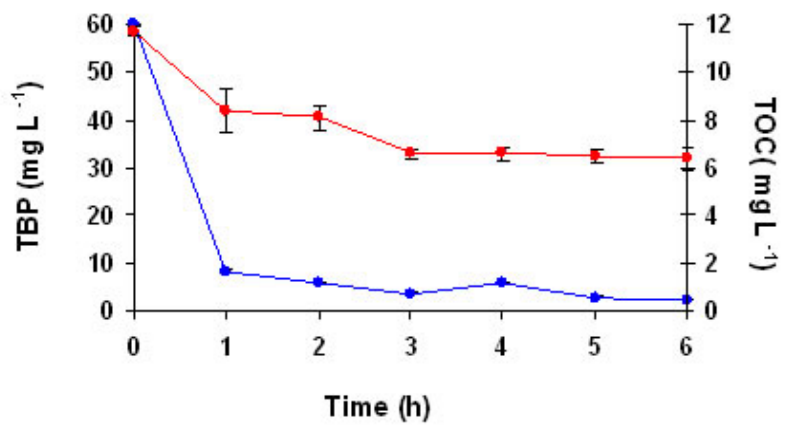

Figure 2. TBP Degradation $(\bullet)$ and mineralization $(\bullet)$ by Hamilton system. (Value represents means \pm S.D. for triplicate culture).

\section{RESULTS AND DISCUSSION}

\section{Biological treatment}

Degradation in liquid culture showed that in the 4 first days of fungi treatment, TBF was degraded almost in a 50\%, being significantly greater the degradation with $G$. trabeum in first day. For the following days, G. australe presented a greater degradation percentage. After 20 days of treatment with $L$. sulphureus, G. trabeum and $G$. australe, the samples presented $48 \%, 74 \%$ and $80 \%$ degradation, respectively (Figure 1). G. australe presented a significantly higher capacity degrading the compound compared to the other fungi. In all treated samples, the AOX diminished considerably (Figure 2), around 70\%, $77 \%$ and $40 \%$ of removal of organic bromine was reached by $G$. trabeum, G. australe and $L$. sulphureus, respectively, This removal was quite proportional to the TBP degradation, indicating a dehalogenation of the compound without the formation of another organo-brominated compound.

To determine TBP biodegradation in a natural substrate, $E$. globulus sawdust was used. The fungus employed was $G$. australe, given the higher degree of degradation that reached in liquid culture. TBP biodegradation in sawdust had an approximated maximum of $23 \%$. This could be due to that the wood is a natural substrate for fungi, becoming the main source of nutrients and limiting compound degradation (cometabolic conditions) (Fahr et al. 1999).

\section{Chemical treatment}

TBP degradation by Hamilton system shows $85 \%$ degradation after $1 \mathrm{hr}$ and 95\% degradation after $5 \mathrm{hrs}$ and then remained constant (Figure 2). The mineralization percentage (TOC removal) and COD reached approximate values $50 \%$ and $48 \%$, respectively. These results showed the limited efficiency of the Hamilton system in the mineralization of TBP. This is a common result in advanced oxidation systems, which generally must be combined with biological treatment (Vidal et al. 2000; Gotvajn and Zagorc-Konèan, 2005). The toxicity expressed as $\mathrm{EC}_{50}$ (effective concentration in percentage terms) of the no-treated compound was 26\%, which represents a concentration of around $15 \mathrm{mg} \mathrm{L}^{-1}$, not changing with further treatment (Table 1).

\section{Chemical-biological combined treatment}

Chemical-biological treatment presented 100\% degradation in 6 days. The toxicity of pre-oxidated samples treated with G. australe and L. sulphureus showed a reduction of $30 \%$ and 34\%, respectively. The sample treated with G. trabeum presented an increase in toxicity of almost $50 \%$, which could be due to compounds produced by this fungus or/and to hydroxylation products of the partial degradation of TBP (Kamada et al. 2002; Newcombe et al. 2002).

Table 1. Toxicity of TBP samples after chemical and chemical-biological combined treatment.

\begin{tabular}{|l|l|}
\hline \multicolumn{1}{|c|}{ Samples } & \multicolumn{1}{c|}{$\mathrm{EC}_{50} \%$} \\
\hline Control & $26.4 \pm 0.9$ \\
\hline $1,2-\mathrm{DHB} / \mathrm{Fe}^{3+} / \mathrm{H}_{2} \mathrm{O}_{2}$ & $26.2 \pm 0.3$ \\
\hline$\left(1,2-\mathrm{DHB} / \mathrm{Fe}^{3+} / \mathrm{H}_{2} \mathrm{O}_{2}\right) /$ G. australe & $36 \pm 3$ \\
\hline$\left(1,2-\mathrm{DHB} / \mathrm{Fe}^{3+} / \mathrm{H}_{2} \mathrm{O}_{2}\right) /$ G. trabeum & $15 \pm 1$ \\
\hline$\left(1,2-\mathrm{DHB} / \mathrm{Fe}^{3+} / \mathrm{H}_{2} \mathrm{O}_{2}\right) /$ L. sulphureus & $40 \pm 1$ \\
\hline
\end{tabular}

\section{CONCLUDING REMARKS}

TBP is a compound resistant to the aerobic biodegradation, but one that can be degraded by wood-degrading fungi. $G$. australe and $G$. trabeum were most efficient than $L$. sulphureus in this bioremediation process, presenting great ability to degrade the compound and remove organic bromine. The Hamilton system reached a high degradation percentage, mineralization and moderate COD reduction. No toxicity increase was observed, which is a favourable 
factor compared with many advanced oxidation processes, in which the degradation products present more toxicity than the original compound. To optimize mineralization, the chemical system could be combined with the fungi biological treatment. This study demonstrated that the combined treatment provides a quite efficient process for the treatment of TBP residuals.

\section{ACKNOWLEDGMENTS}

The authors thank the ALFA-European Union Program, the FONDECYT-Chile Program (grant $N^{\circ}$ 1040619) and the Graduate School, UDEC.

\section{REFERENCES}

CONAMA. Rubro aserraderos y procesos de madera. Guía para el control y prevención de la. contaminación industrial [online]. Chile; National Commission of the Environment, December 2000 [cited 22 February 2004]. Available from Internet: http://www.conama.cl/portal/1255/articles26228_pdf_aserraderos.pdf.

EPA. Organobromine production wastes; Identification and listing of hazardous waste; Land disposal restrictions; Listing of CERCLA hazardous substances, reportable quantities. [online]. USA; Environmental Protection Agency (EPA), 1998 [cited 3 November 2003]. Available from Internet: http://www.epa.gov/epaoswer/hazwaste/state/revision/frs/fr 165.rtf.

EGGEN, T. Application of fungal substrate from commercial mushroom production- Pleurotus ostreatus for bioremediation of creosote contaminated soil. International Biodeterioration Biodegradation, September -October 1999, vol. 44, no. 2-3, p. 117-126.

FAHR, K.; WETZSTEIN, H.-G.; GREY, R. and SCHLOSSER, D. Degradation of 2,4-dichlorophenol and pentachlorophenol by two brown rot fungi. FEMS Microbiology Letters, June 1999, vol. 175, no. 1, p. 127132.

GOTVAJN, A.Ž. and ZAGORC-KONÈAN, J. Combination of Fenton and biological oxidation for treatment of heavily polluted fermentation waste broth. Acta Chimica Slovenica, June 2005, vol. 52, no. 2, p. 131137.

JENSEN, K.; HOUTMAN, C.; RYAN, Z. and HAMMEL, K. Pathways for extracellular Fenton chemistry in the brown rot basidiomycete Gloephyllum trabeum. Applied and Environmental Microbiology, June 2001, vol. 67, no. 6, p. 2705-2711.

KAMADA, F.; ABE, S.; HIRATSUKA, N.; WARIISHI, H. and TANAKA, $\mathrm{H}$. Mineralization of aromatic compounds by brown-rot basidiomycetes-mechanisms involved in initial attack on the aromatic ring. Microbiology, June
2002, vol. 148, no. 6, p.1939-1946.

NEWCOMBE, D.; PASZCZYNSKI, A.; GAJEWSKA, W.; KRÖGER, M.; FEIS, G. and CRAWFORD, R. Production of small molecular weight catalysts and the mechanism of trinitrotoluene degradation by several Gloeophyllum species. Enzyme and Microbial Technology, April 2002, vol. 30, no. 4, p. 506-517.

PASZCZYNSKI, A.; CRAWFORD, R.; FUNK, D. and GOODELL, B. De novo synthesis of 4,5dimethoxycatechol and 2,5-dimethoxyhydroquinone by the brown rot fungus Gloeophyllum trabeum. Applied and Environmental Microbiology, February 1999, vol. 65, no. 2, p. 674-679.

QIAN, Y.; GOODELL, B. and FELIX, C. The effect of low molecular weight chelators on iron chelation and free radical generation as studied by ESR measurement. Chemosphere, July 2002, vol. 48, no. 1, p. 21-28.

ROJO, K.; CONTRERAS, D.; VALENZUELA, R.; FREER, J. and RODRÍGUEZ, J. Degradación de 2,4,6Tribromofenol por reacción de Fenton Asistida por Catecol. In: VII Encuentro de Química Analítica y Ambiental,Oral A2. (October 2004, Serena, Chile).

SCHÜTZENDÜBEL, A.; MAJCHERCZYK, A.; JOHANNES, C. and HÜTTERMANN, A. Degradation of fluorene, anthracene, phenanthrene and pyrene lacks connection to the production of extracellular enzymes by Pleurotus ostreatus and Bjerkandera adusta. International Biodeterioration Biodegradation, April 1999, vol. 43, no. 3, p. 93-100.

SHOLOSSER, D.; FAHR, K.; KARL, W. and WETZSTEIN, H.-G. Hydroxylated metabolites of 2, 4dichlorophenol imply a Fenton-type reaction in Gloephylum striatum. Applied and Environmental Microbiology, June 2000, vol. 66, no. 6, p. 2479-2483.

SHIMADA, M.; AKAMTSU, Y.; TOKIMATSU, T.; MII, K. and HATTORI, T. Possible biochemical roles of oxalic acid as a low molecular weight compound involved in brown-rot and white-rot wood decays. Journal of Biotechnology, March 1997, vol. 53, no. 2-3, p. 103-113.

VIDAL, G.; NIETO, J.; MARQUEZ, F.; MANSILLA, H. and BORNHARDT, C. Combinación de procesos biológicos y oxidación avanzada para el tratamiento de una corriente de proceso de la industria de curtiembre. Estrucplan, 2000 [online]. Argentina. Last updated 1 January 2000 [cited 4 august 2004]. Available from Internet:

http://www.estrucplan.com.ar/Articulos/verarticulo.asp?ID Articulo=592.

WANG, W. and GAO, P.J. Function and mechanism of a low-molecular-weight peptide produced by Gloeophyllum 
trabeum in biodegradation of cellulose. Journal of Biotechnology, March 2003, vol. 101, no. 2, p. 119-130.

YADAV, J. and REDDY, A. Mineralization of 2,4Dichlorophenoxyacetic acid (2,4-D) and mixtures of 2,4-D and 2,4,5-trichlorophenoxyacetic acid by Phanerochaete chrysosporium. Applied and Environmental Microbiology, September 1993, vol. 59, no. 9, p. 2904-2908. 